\title{
Análise de discurso como ferramenta fundamental dos estudos de Segurança - Uma abordagem Construtivista
}

\section{Guilherme Frizzera ${ }^{1}$}

\section{RESUMO}

A Análise de Discurso (AD) é uma ferramenta essencial para os estudos de Segurança nas Relações Internacionais. A proposta desse artigo consiste em fazer uma breve e sucinta discussão sobre a importância dos discursos, tendo como base o chamado Construtivismo Crítico.

Palavras-Chaves: Análise de Discurso; Construtivismo; Segurança.

A Análise de Discurso (AD) está presente nas teorias de Relações Internacionais principalmente a partir do final da década de 1980. Com o surgimento do Construtivismo, autores como Friedrich Kratochwil e Nicholas Onuf apontam a importância do discurso como ferramenta fundamental de análise. Definido como "Construtivismo Crítico", em contraposição ao posterior "Construtivismo Convencional” de Alexander Wendt, a vertente aproxima-se do Pós-Positivismo, isto é, baseia-se no poder dos discursos, linguagem, realidade e significado, adotando uma abordagem cautelosa para as reivindicações de verdade e as relações de poder (FIERKE; JORGENSEN, 2001).

O Construtivismo Crítico entra em choque com o Construtivismo Convencional, pois o segundo tende a ratificar o Estado como objeto de análise principal nos assuntos de segurança. No entanto, o Construtivismo Crítico tende a refletir o Construtivismo Convencional, ao não abordar, explicitamente, os conceitos de segurança (BUZAN; HANSEN, 2012).

Os trabalhos de Onuf, Kratochwil e Fierke focam como a linguagem é crucial em termos de compreensão dos significados e interpretação do relacionamento entre palavra e mundo (Word and World). Onuf relaciona regras de linguagem, tomando a noção de Wittgenstein de que ela é semelhante às regras de um jogo (AGIUS, 2010 apud

\footnotetext{
${ }^{1}$ Graduado em Relações Internacionais pelas Faculdades Integradas Rio Branco. Mestrando em Integração da América Latina pela Universidade de São Paulo (PROLAM/USP).
} 
COLLINS, 2010). Atos de fala - que relacionam linguagem a ação - e regras constituem os atores. Onuf (et al., 1998) identifica três tipos de atos de fala: assertivos, diretivos e compromisso (commitments). Os "atos assertivos" relacionam conhecimento sobre o mundo (por exemplo, que democracias não entram em guerra com outra democracia). Os "atos diretivos" nos fornecem instruções: o que fazer, o que irá acontecer se falharmos em fazer algo. E, finalmente, os "atos de compromisso" vinculam as promessas (como assinar um tratado, por exemplo). Examinando os significados que os atos de fala invocam, ganhamos um forte senso de como a linguagem estrutura o mundo e as relações, além de um senso mais complexo de comunicação entre os atores. A linguagem é constitutiva e não simplesmente representa o mundo como ele é. Segundo Onuf (et al., 1998,), discurso produz regras e políticas, e expressa nossos objetivos e intenções.

Linguagem e atos de fala têm enorme importância para os estudos de segurança porque eles têm poder de "securitizar", como observa Huysmans (2002, pp. 44-45, tradução nossa): "Linguagem não é apenas um instrumento de comunicação utilizado para falar de um mundo real fora da linguagem; É uma força definidora, integrando as relações sociais". A linguagem de segurança pode criar um cenário diferente acerca de um problema social ou sobre a fonte que gera insegurança. O Construtivismo Crítico afirma que as definições de segurança são construídas discursivamente através de representações e de elementos linguísticos - substantivos, adjetivos, metáforas e analogias (BUZAN; HANSEN, 2012). Ademais, as políticas de segurança não nascem somente de um interesse objetivo, mas são legitimadas através das "regras do jogo" criadas discursivamente (FIERKE; JORGENSEN, 2001).

O "conhecimento de segurança" produzido pelas agências de segurança e as forças militares, os outros corpos oficiais do governo, e pela imprensa são poderosos na articulação sobre ameaças ou perigos. Falar ou escrever pode construir problemas de segurança. Aqueles que implantam a linguagem quando examinam a construção de uma ameaça, perigo e identidade ganham melhor compreensão da complexidade do assunto e, até mesmo, da própria construção da ameaça.

O Construtivismo Crítico visa a desnaturalizar a identidade e a lógica através da qual compreendemos o mundo, concentrando-se no contexto de interação e significados intersubjetivos. Fierke e Jorgensen (2001) exemplificam ao tratar do caso da Ruanda. 
Proferindo um pedido de desculpas ou descrever um conflito como "genocídio" tem implicações para o significado e a ação, constituindo o que é possível e o que não é. A relutância dos EUA em classificar os fatos como genocídio e sim como uma guerra tribal, isso implicaria a não intervenção do país em Ruanda, invocando, principalmente, o conceito de soberania.

Autores que dirigem seus estudos para a área de segurança, como os acadêmicos da Escola de Copenhagen, apontam a importância do discurso nos estudos de segurança. Uma das principais contribuições está no chamado "processo de securitização". Qualquer assunto pode ser "não politizado", "politizado" e "securitizado". Resumidamente, no primeiro estágio, o Estado não lida com o assunto e o mesmo não é alvo de debate público. No segundo estágio, o assunto é parte da agenda de políticas públicas do governo. No último estágio, o assunto torna-se questão de segurança através de um processo de securitização, onde o objeto pode ser uma ameaça ou alvo de uma ameaça (BUZAN et al., 1998). O processo de securitização é dividido em dois estágios: o primeiro diz respeito à interpretação de certas questões, pessoas ou entidades como ameaças existenciais para objeto referente. Não necessariamente a inicialização da securitização depende somente do Estado, mas atores não-estatais podem iniciar o movimento. No segundo estágio, o processo de securitização terá sucesso somente quando o ator (ou atores) que iniciaram o processo de securitização obtenha sucesso em convencer a audiência (opinião pública, políticos, militares e outras elites) da necessidade do assunto se tornar objeto de segurança (BUZAN et al., 1998).

Ressalta-se que no processo de securitização, são de suma importância os atos de fala. Esta última etapa do modelo é definida como a representação discursiva de uma determinada questão como uma ameaça existencial à segurança. A Escola de Copenhagen considera o ato de fala sendo o ponto de partida do processo de securitização. Uma questão pode se tornar "de segurança" durante todo o ato de fala por si só, independentemente da preocupação representar uma ameaça existencial em termos materiais. $\mathrm{O}$ ator que iniciou o processo de securitização usa a linguagem para articular um problema em termos de segurança e para persuadir uma audiência relevante de seu perigo imediato. 
A securitização se refere, segundo Barry Buzan e Lene Hansen (2012, p. 323), "ao processo de apresentar uma questão em termos de segurança”. Em outras palavras,

\begin{abstract}
A maneira de estudar securitização é estudar o discurso e as contestações políticas: quando um argumento dentro desta estrutura retórica e semiótica específica atinge um efeito suficiente para fazer um público tolerar violações de regras que, de outro modo, deveriam ser obedecidas? Se, por meio de um argumento acerca da prioridade e da urgência de uma ameaça existencial, o ator securitizante conseguiu se libertar dos procedimentos ou das regras aos quais ele ou ela deveria estar vinculado(a), estamos testemunhando um caso clássico de securitização. (BUZAN et al., 1998 apud BUZAN; HANSEN, 2012, pp. 323-324).
\end{abstract}

Portanto, destaca-se a importância da AD nos estudos de segurança nas Relações Internacionais. Não que somente os discursos importam nessa área. Estudos da Paz, Estudos Estratégicos e a Geopolítica constituem fatores determinantes para um estudioso de segurança. Porém, desconsiderando os fatores não materiais e subjetivos nas análises, tornam qualquer estudo de segurança incompleto. Como afirma Onuf (1989), "dizer é fazer". As ações em matéria de segurança surgem a partir do momento em que o assunto assume pauta no discurso oficial, assim como, os métodos empregados para a resolução serão justificados e, até mesmo, limitados através do discurso. É de suma importância analisar discursos para entender qualquer objeto que seja alvo de pesquisa de segurança nas Relações Internacionais.

\title{
Referências Bibliográficas
}

BUZAN, Barry; Hansen, Lene. A Evolução dos Estudos de Segurança Internacional. São Paulo: Ed. Unesp, 2012.

BUZAN, Barry; WAEVER, Ole; WILDE, Jaap. Security: The New Framework for Analysis. Boulder: Lynne Rienner, 1998.

COLLINS, Alan. Contemporany Security Studies. New York: Oxford University Press, 2010.

FIERKE, Karin M.; JORGENSEN, Knud Erik. Constructing International Relations: The Next Generation. New York: M. E. Sharpe, 2001.

HUYSMANS, Jef. Defining Social Constructivism in Security Studies: The Normative Dilemma of Writing Security. Alternatives, 27, 2002, pp. 41-62. 
ONUF, Nicholas. World of Our Making: Rules and Rule in Social Theory and International Relations. Columbia: University of South Carolina Press, 1989.

ONUF, Nicholas; KUBÁLKOVÁ, Vendulka; KOWERT, Paul. International Relations in a Constructed World. New York: M. E. Sharpe, 1998. 